Nijaz Skender ${ }^{1}$, Sulejman Kendić ${ }^{2}$ i Indira Dupljak, prof. ${ }^{3}$

\title{
ANALIZA RAZLIKA NEKIH ANTROPOLOŠKIH OBILJEŽJA UČENIKA SA POSEBNIM POTREBAMA I UČENIKA IZ NORMALNE POPULACIJE
}

\section{SAŽETAK}

Djeca sa posebnim potrebama trebala bi biti briga svakog društva i tom problemu bi trebalo posvetiti mnogo veću pažnju. Takva djeca su danas u većini zajednica odvojena u posebne škole. Takvih škola je manje u posljednje vrijeme jer je intencija da se $i$ oni uključuju u redovne škole. Međutim, tamo gdje je stepen retardacije tako visok da ne omogućuje praćenje redovnog nastavnog plana $i$ programa, za njih postoje specijalne škole. $U$ dosadašnjim istraživanjima su utvrđene velike korelacije između pojedinih antropoloških obilježja i nivoa mentalne retardacije.

U ovom radu došl ismo do zaključka da se učenici koji imaju visoki nivo retardacije značajno razlikuju u morfološkim karakteristikama i motoričkim sposobnostima. Te razlike su se ogledale u tako značajnim odnosima da su učenici sa mentalnom retardacijom u morfološkom smislu bili teži $18 \mathrm{~kg}$ u istoj hronološkoj dobi. To se naravno odrazilo i ma stepen motoričkih sposobnosti, koje su se najviše odrazile na koordinaciju koja je jako bitna za kompletno motoričko djelovanje. Učenici sa mentalnom retardacijom su u svim motoričkim sposobnostima pokazali značajno niži nivo motoričkih sposobnosti od učenika koji dolaze iz normalne populacije, jer su i motoričke sposobnosti u velikoj korelaciji sa svim psihološkim manifestacijama kod ljudi. Radeći na razvoju motoričkih sposobnosti možemo sasvim sigurno uticati i na poboljšanje psihičkih funkcija.

Ključne riječi: morfološke karakteristike, motoričke sposobnosti, učenici sa posebnim potrebama.

\footnotetext{
${ }^{1}$ Dr. sc. Nijaz Skender, docent, Pedagoški fakultet, Bihać.

${ }^{2}$ Prim. dr. sc. Sulejman Kendić, vanredni profesor, Dom zdravlja Velika Kladuša,

${ }^{3}$ Indira Dupljak, prof., asistent na Nastavničkom fakultetu Univerziteta u Mostaru.
} 


\section{UVOD}

Tjelesno vježbanje je jedan jedinstveni psihomotorički proces u kojem se ostvaruju konkretni zadaci tjelesnog i zdravstvenog odgoja višestrukim metodski organiziranim ponavljanjem istih ili različitih motoričkih pokreta. To je motoričko gibanje koje čovjek izvodi i primjenjuje radi rješavanja određenog motoričkog zadatka. Proces vježbanja podrazumijeva primjenu sasvim određenih struktura kinezioloških stimulansa s obzirom na sadržaj, volumen i modalitet rada. Tjelesna vježba za djecu i omladinu predstavlja jedan od važnih poticaja rasta i razvoja, a da bi ono bilo efikasno, treba im osigurati dovoljno kretanja i izabrati tjelesne vježbe koje su primjerene njihovom hronološkom, biološkom i mentalnom uzrastu. Određene tjelesne vježbe ne utiču podjednako na svakog pojedinca, što ovisi i o uvjetima pod kojima se izvodi te vježbe. Sam doživljaj uspjeha pri kretanju kod ove djece dovodi do podizanja nivoa samopouzdanja, dovodi do razvoja osjećaja lične vrijednosti, povećava sposobnost kontrole ponašanja u socijalnoj sredini u kojoj žive, te na taj način sopstveni život, taj i takav, podižu na jedan određeni nivo životnog kvaliteta ako se on uopće može nazvati takvim. Izliječiti bolest ili zaustaviti njeno napredovanje znači otvoriti vrata u smisao života.

Ovim radom želim pomoći svim onim koji rade sa djecom sa posebnim potrebama kako bi razumjeli problem i dinamiku nastajanja različitih psihofizičkih problema i da kroz to izvode visoko stručan, ali i nadasve human pristup tako složenoj problematici. Polazeći od pretpostavke da je svaka ljudska jedinka neponovljivi prirodni eksperiment dolazimo do spoznaje da smo svi medusobno različiti. Ljudi se međusobno razlikuju po mnogim karakteristikama i sposobnostima, a da smo svi zaista međusobno različiti potvrđuju istraživanja koja su pokazala individualne razlike čak i kod jednojajčanih i dvojajčanih bliznaca.

Pokušamo li pronaći odgovor na pitanje zbog čega se ljudske jedinke međusobno razlikuju, neminovno je u tom traganju eksploatirati saznanja antropologije - nauke koja proučava čovjeka sa anatomskog, fiziološkog, psihološkog, historijskog, sociološkog i niza drugih aspekata.

Pošto antropologija izučava čovjeka u prostoru i vremenu od njegovog postanka do danas, njen interdisciplinirani metodološki pristup izučavanja ove problematike daje odgovore na pitanja od čega 
i u kojoj mjeri zavise ontogenetski procesi ljudskih sposobnosti i karakteristike. Antropologija posmatra čovjeka kao cjelinu, što znači da se zakonitosti razvoja ljudskog bića objašnjavaju integralno, pošto je svaki problem vezan za ljudsku jedinku u užoj međuzavisnosti prirodnih i društvenih faktora. Pri proučavanju rasta i razvoja jedinka se mora posmatrati kao dio sredine sa kojom razmjenjuje materiju i energiju i bez koje sigurno ne bi mogla opstati. Tokom cijelog života na ljudski organizam djeluju različiti unutrašnji i spoljnji faktori koji zajedno i u sadejstvu sa genetičkim faktorima određuju sva njegova biološka svojstva.

Svi unutrašnji (endogeni) faktori su pod kontrolom genetskih, hormonalnih i nervnih faktora. U spoljašnje (egzogene) faktore ubrajaju se: klimatsko-ekološki, nutricioni, zdravstveno-higijenski i socioekonomski faktori. Spoznati i govoriti o antropološkom statusu čovjeka je nemoguće bez poznavanja njegovih antropoloških obilježja u koje ubrajamo: morfološke karakteristike, funkcionalne, motoričke, konativne i kognitivne sposobnosti, biomehaničke informacije i sociološke karakteristike.

Iz navedenog je jasno vidljiva sva kompleksnost ljudske ličnosti. Zato naučnici koji istražuju pojedine segmente antropološkog statusa čovjeka moraju maksimalno profesionalno i tačno da pristupe planiranju i realizaciji svih poslova i zadataka koji su sastavni dijelovi naučnoistraživačkog rada.

Galton je prvi predložio rangiranje ljudi prema općoj inteligenciji $u$ četrnaest kategorija od imbicila $i$ idiota do najinteligentnijih ljudi. MC Keen Gattell, Galtonov učenik, pošao je istim putem, tj. želio je na osnovu mjerenja jednostavnih senzornih $\mathrm{i}$ motoričkih funkcija, kao npr. sposobnosti diskriminacije i testova snage i brzine, dijagnosticirati razvoj mentalnih sposobnosti ispitanika. Značaj njegovih radova je u tome što je uočio veći značaj povezanosti inteligencije i motoričkih sposobnosti.

Integrirajući Spirmanovu ideju o općoj mentalnoj sposobnosti koja se u većoj ili manjoj mjeri manifestira u svakom spoznajnom procesu s rezultatima koji su ukazivali na postojanje faktora, Burf (1949) izgrađuje hijerarhijski model strukture inteligencije. On smatra da se, ovisno o složenosti, mentalni procesi i mentalne sposobnosti mogu razvrstati u četiri nivoa. Najjednostavniji u hijerarhiskoj strukturi je nivo jednostavnih senzomih procesa i elementernih motoričkih reakcija. S obzirom na senzorne procese postoji niz vrlo 
specifičnih diferenciranih faktora koji se razlikuju po sadržaju. To su osjeti vida, sluha, mirisa i kinestezije. Sljedeći je nivo perceptivnih procesa i složenih motoričkih reakcija. Na trećem, asocijativnom nivou faktore je moguće difirencirati kako s obzirom na kognitivnu aktivnost, tako i s obzirom na sadržaj. Najviši nivo je nivo logičkog mišljenja i estetskog vrednovanja, a za to je neophodna sposobnost razumijevanja apstraktnih odnosa.

Sposobnost logičkog mišljenja čine dva faktora: faktor razumijevanja relacija $\mathrm{i}$ faktor kombiniranja relacija. $\mathrm{U}$ prostoru drugog, višeg reda Vernon pretpostavlja postojanje niza mnogih grupnih faktora kao što su kreativne sposobnosti, jezičke sposobnosti, sposobnosti čitanja, pisanja, matematičke sposobnosti te psihomotorne i fizičke sposobnosti i sposobnosti korištenja mehaničkih informacija. Danas prevladava mišljenje da je opće spoznajno funkcioniranje prvenstveno definirano stanjem i funkcioniranjem cijelog CNS. Hebb ističe (1966) značaj inhibitornih mehanizama, koji prema njegovom mišljenju omogućavaju ispitaniku da na podražaj ne reagira odmah, već da iz niza stvorenih veza između podražaja i reakcije izabere onu koja je u datom trenutku najadekvatnija. Hebbu upravo te mogućnosti „odložene" reakcije predstavljaju pojavu prvog kognitivnog ponašanja. Lurija je (1976) u svojim radovima objavio da svi mentalni procesi ovise o aktivnostima triju blokova: bloka za regulisanje tonusa i stanja budnosti, bloka za prijem, transformaciju i pohranjivanja informacija i bloka za programiranje, regulisanje i kontrolu najsloženijih oblika ponašanja čovjeka.

Pod znatnim uticajem ispitivanja individualnih razlika $u$ spoznajnom funkcioniranju, odnosno pojma mentalne dobi i QI kao mjere opće spoznaje sposobnosti, prva ispitivanja individualnih razlika i motoričkih aktivnosti zasnovane su na pretpostavci da postoji jedna opcija motoričke sposobnosti. Ideje nastale na području testiranja inteligencije najizrazitije su se odrazile u radu Ozeretskog, koji predlaže da se nakon zadataka ispita opći motorički faktor, te da se učinak ispitanika izrazi motoričkim koeficijentom (1925).

Ideju o postojanju opće motoričke sposobnosti zastupa i Brace (1926), koji stvara bateriju testova za ispitivanja motoričke sposobnosti sa 30 zadataka. Brace smatra da se na osnovu rezultata $u$ bateriji može ne samo dijagnosticirati sposobnost ispitanika da usvoji nove motoričke vještine već i prognozirati efikasnost koju ispitanik može postići na kraju učenja te vještine. 
Mc Cloy (1934) takoder prihvata pretpostavku o postojanju faktora opće motoričke spobnosti. On smatra da mjerni instrumenti kojima bi se procjenjivala opća motorička sposobnost ispitanika trebaju biti nalik testovima inteligencije, tj. sadržavati takve zadatke koji će okupirati ispitanika u svim antropološkim segmentima, te na taj način dati prave pokazatelje o antropološkom statusu ispitanika.

\section{METODE RADA \\ 2.1. PREDMET I PROBLEM ISTRAŽIVANJA}

U školskom sistemu se javljaju teškoće zbog toga što izvjestan broj učenika nije u stanju da prati redovnu nastavu zbog ograničene intelektualne sposobnosti. Kako redovna škola nije bila spremna da im se prilagodi, svojim načinom rada, programima i zahtjevima, javlja se ideja da se takvi učenici selekcioniraju i odvoje u posebne razrede. Takvih škola i razreda na području Bosne i Hercegovine ima nekoliko a mi smo se za ovaj rad opredijelili da analiziramo antropološki status učenika jedne takve osnovne škole koja je locirana u Mostaru. Postoje različite teorije evolucije a sve potiču zanimanje za ispitivanje individualnih razlika, a naročito onih koje znatno doprinose adaptaciji čovjeka na prijem, transformaciju i interpretaciju usvojenih ili ponuđenih sadržaja. U ovom istraživanju urađeno je mjerenje i testiranje nekih morfoloških karakteristika i motoričkih sposobnosti ispitanika - djece sa lakšim, umjerenim i srednje teškim oblikom mentalne retardacije, koja su pohađala nastavu po specifičnom planu i programu, kao i mjerenje i testiranje istih varijabli kod zdrave djece, istog hronološkog uzrasta, koja su pohađala redovnu nastavu tjelesnog i zdravstvenog odgoja u toku jedne školske godine.

Predmet ovog istraživanja je nastava tjelesnog i zdravstvenog odgoja kod djeca sa posebnim potrebama, odnosno transverzalni presjek njihovih motoričkih sposobnosti i morfoloških karakteristika te njihova komparacija u odnosu na djecu istog hronološkog uzrasta koja pohađaju redovnu nastave.

\subsection{CILJ I ZADACI ISTRAŽIVANJA}

Na osnovu predmeta i problema ovog rada, a uzimajući u obzir dosadašnja istraživanja antropološkog statusa djece sa posebnim 
potrebama u odnosu na djecu koja su pohađala redovnu nastavu, postavili smo cilj i zadatke ovog rada.

\subsection{Cilj rada}

Primarni cilj ovog rada jeste da se utvrdi nivo kvantativnih i kvalitativnih razlika motoričkih sposobnosti i morfoloških karakteristika djece sa posebnim potrebama te da se isti rezultati uporede sa rezultatima djece koja su pohađala redovnu školu. Ti rezultati će nam dati informaciju o stepenu antropološkog razvoja dviju grupa ispitanika te da $\mathrm{u}$ nastavi planiramo aktivnosti za poboljšanje antropoloških obilježja naročito kod djece sa mentalnom retardacijom.

\subsection{Zadaci rada}

U cilju davanja adekvatnog odgovora na predmet, problem kao i cilj ovog rada definisali smo i sljedeće zadatke ovog rada:

-konsultacija adekvatne literature o antropološkom statusu djece sa posebnim potrebama,

-studiozna analiza dosadašnjih istraživanja, čiji predmet su bila djeca sa posebnim potrebama,

-utvrđivanje testova za procjenu morfološkog i motoričkog statusa, -testiranje djece/učenika sa posebnim potrebama i djece/učenika redovne škole,

-komparativna analiza dobivenih rezultata,

-uvrđivanje razlika i donošenje utilitarnih zaključka.

\subsection{Uzorak ispitanika}

Populacija ispitanika u ovom istraživanju je definisana kroz dva segmenta:

- prvi segment su predstavljala djeca - učenici školskog Centra za djecu i omladinu sa posebnim potrebama u Mostaru, i to svi učenici, što ukupno iznosi 23 ispitanika,

- drugi segment su predstavljala djeca - učenici OŠ «Čerin» iz Čitluka - 59 ispitanika. 
Svi ispitanici, u okviru svojih škola, bili su uključeni u redovni program nastave tjelesnog i zdravstvenog odgoja kroz dva nastavna sata tjedno. Prilikom obrade rezultata u obzir su uzeti samo oni ispitanici koji su izvršili sva mjerenja morfoloških i motoričkih sposobnosti.

\subsection{Uzorak varijabli}

Pri odabiru varijabli korišteni su rezultati dosadašnjih istraživanja, a odabrane su one varijable kod kojih su utvrđene metrijske karakteristike (valjanost, pouzdanost, objektivnost i dr.), a koje su bile primjerene ovoj uzrasnoj kategoriji. Odabrane varijable $\mathrm{u}$ ovom istraživanju hipotetski će pokriti prostore opće motorike (14 varijabli) i prostor morfologije (14 varijabli).

\section{Morfološke varijable}

Ukupno je izmjereno 14 varijabli za procjenu morfoloških karakteristika, a to su:

1. AVIS

2. ATEŽ

3. ADUR

4. ADUS

5. ABIKR

6. ABIAR

7. ADIRZ

8. ADIKO

9. AKNNL

10. AKNLE

11. AKNTR

12. AOGK

13. AOPOTK

14. AONADL
( visina tijela)

(težina tijela)

(dužina ruku)

(dužina stopala)

(bikondilarni raspon)

(biakromijalni raspon)

(dijametar ručnog zgloba)

(dijametar koljenog zgloba)

(kožni nabor nadlaktice)

(kožni nabor leđa)

(kožni nabor trbuha)

(obim grudnog koša)

(obim potkoljenice)

(obim nadlaktice)

\section{Varijable za procjenu motoričkog statusa ispitanika}

Za procjenu motoričkih sposobnosti korištena je baterija testova od 14 varijabli:
1. MBTR
(taping rukom)
2. MBTN
(taping nogom)
3. MBTNZ
(taping nogom od zid) 

4. MEST20M
(trčanje $20 \mathrm{~m}$ - visoki start)
5. MESSDM
(skok u dalj iz mjesta)
6. MRSPTT
(podizanje trupa za trbuh)
7. MRSDĆ
(duboki čučnjevi)
8. MRSIZZ
(izdržaj u zgibu)
9. MKOSDN
(skok u dalj natraške)
10 MKOPZD
(pretklon-zasuk-dodir)
11. MKOT10x5
(trčanje $10 \mathrm{~m}$ 5x tamo-ovamo)
12. MFDP
13. MFIP
(dohvat u pretklonu)
(iskret palicom)
14. MFPSR
(pretklon sjedeći - raskoračno)

NAPOMENA: Sve antropometrijske mjere su uzete i mjerene po metodi koju preporučuje Internacionalni biološki program (IBP).

\section{REZULTATI SA DISKUSIJOM}

Najjednostavniji slučaj razlikovanja dviju skupina ispitanika je kada se analiziraju razlike između aritmetičkih sredina te dvije grupe ispitanika na osnovu jedne manifestne ili latentne varijable. Test za testiranje značajnosti razlika između aritmetičkih sredina dviju grupa ispitanika u jednoj varijabli naziva se T-test.

$\mathrm{Na}$ osnovu T-testa utvrđuje se ustvari koliko je puta razlika dviju aritemtičkih sredina veća od svoje pogreške. Smatra se da je ta razlika statistički značajna ako je najmanje dva puta veća od svoje pogreške od $\mathrm{P}=.05$.

\section{Centralni disperzivni parametri}

Vrijednosti centralnih disperzivnih parametara nam ukazuju na normalnost distribucija primijenjenih manifestnih varijabli kod ispitanika koji dolaze iz normalne populacije. Kada su u pitanju učenici sa posebnim potrebama s obzirom na stepen retardacije, vidjeli smo da postoje određene razlike u pojedinim testovima, međutim one nisu uticale na daljnji tok istraživanja. Rezultati centralnih disperzivnih parametara su prikazani u donjoj tabeli za morfološke karakteristike kod obe grupe ispitanika.

\section{Procjena morfološkog statusa za obje grupe ispitanika}


Tabela br. 1.

Group Statistics

\begin{tabular}{|c|c|c|c|c|c|c|c|c|c|}
\hline & 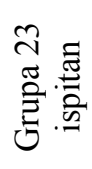 & $\sum_{\Sigma}^{\varpi \Xi}$ & 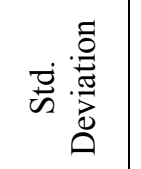 &  & & 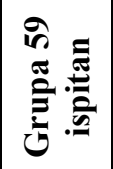 & $\sum_{\Sigma}^{\bar{E}}$ & 总 &  \\
\hline avis & 1,00 & $\begin{array}{r}159,773 \\
9 \\
\end{array}$ & $\begin{array}{r}12,9344 \\
9\end{array}$ & 2,69703 & avis & 2,00 & 159,1356 & 7,56685 & ,98512 \\
\hline adur & 1,00 & 69,8826 & 9,49673 & 1,98020 & adur & 2,00 & 67,8712 & 3,05287 & ,39745 \\
\hline adus & 1,00 & 24,4478 & 2,37580 & 49539 & adus & 2,00 & 23,1763 & 1,31639 & ,17138 \\
\hline abiar & 1,00 & 34,6826 & 3,52287 & ,73457 & abiar & 2,00 & 29,9542 & 3,10885 &, 40474 \\
\hline abikr & 1,00 & 24,8174 & 3,29030 & ,68607 & abikr & 2,00 & 24,5763 & 1,35447 &, 17634 \\
\hline adirz & 1,00 & 5,0565 & ,51683 & ,10777 & adirz & 2,00 & 4,9975 &, 37548 &, 04888 \\
\hline adiko & 1,00 & 9,6783 & $\begin{array}{l}1,30592 \\
\end{array}$ & 27230 & adiko & 2,00 & 8,8475 &, 74344 &, 09679 \\
\hline aknnl & 1,00 & 14,7565 & 8,35088 & 1,74128 & aknnl & 2,00 & 5,4919 & 2,80820 & ,36560 \\
\hline aknle & 1,00 & 18,7696 & 9,48206 & 1,97715 & aknle & 2,00 & 4,8444 & 2,70839 &, 35260 \\
\hline akntr & 1,00 & 14,3217 & 9,19288 & 1,91685 & akntr & 2,00 & 5,4046 & 3,13656 & ,40835 \\
\hline aogk & 1,00 & 85,9261 & $\begin{array}{r}13,6218 \\
5\end{array}$ & 2,84035 & aogk & 2,00 & 70,9661 & 2,51866 & ,32790 \\
\hline \begin{tabular}{|l|} 
aopot \\
k
\end{tabular} & 1,00 & 34,4652 & 5,25354 & 1,09544 & aopotk & 2,00 & 30,8644 & 2,30036 & ,29948 \\
\hline aonadl & 1,00 & 24,9826 & 4,83309 & 1,00777 & aonadl & 2,00 & 21,0169 & 1,29311 &, 16835 \\
\hline atež & 1,00 & 59,6043 & $\begin{array}{r}21,8823 \\
0\end{array}$ & 4,56277 & atež & 2,00 & 41,2136 & 7,88586 & 665 \\
\hline
\end{tabular}

Na uzorku od 59 ispitanika - učenika koji su pohadjali redovnu školu, primijenjena je baterija od 14 testova morfoloških karakteristika čime je pokriven morfološki prostor u sve četiri dimenzije. Aritmetičke sredine i standardne devijacije su prikazane u gornjoj tabeli.

Poređenjem rezultata dviju aritmetičkih sredina ispitanika sa posebnim potrebama i ispitanika koji pohađaju školu po redovnom planu i programu, možemo zaključiti da su evidentne razlike u slijedećim morfološkim varijablama.

Varijable za procjenu mase i volumena tijela iskazuju znatno veće vrijednosti kod djece sa posebnim potrebama, u odnosu na normalnu djecu:

- $\quad$ djeca sa posebnim potrebama su u prosjeku teža $18,40 \mathrm{~kg}$ od normalne djece,

- obim nadlaktice djece sa posebnim potrebama je u prosjeku veći 
za $3,97 \mathrm{~cm}$,

- obim potkoljenice je također veći kod djece sa posebnim potrebama u prosjeku za $3,6 \mathrm{~cm}$,

- obim grudnog koša kod djece sa posebnim potrebama je u prosjeku veći za 14,96 cm,

- $\quad$ varijable kožnih nabora nam također daju pokazatelje da djeca sa posebnim potrebama imaju u prosjeku znatno veće vrijednosti.

Varijable za procjenu longitudinalne dimenzionalnosti skeleta

- Prosječne vrijednosti su skoro indentične sa vrlo malim i neznatnim odstupanjima u korist djece sa posebnim potrebama.

Varijable za procjenu transverzalne dimenzionalnosti skeleta

- One su također u prosjeku veće u korist djece sa posebnim potrebama.

Upravo svi prethodno pobrojani pokazatelji morfoloških karakteristika djece sa posebnim potrebama i normalne djece govore nam da su vrijednosti ove prve populacije u prosjeku znatno veće što je u suštini posljedica vrlo niskog stepena motoričke inteligencije i motoričkih sposobnosti. Međutim, prateći varijable za procjenu longitudinalne dimenzionalnosti skeleta vidjećemo da su vrijednosti i jedne i druge populacije približno iste, što se može tumačiti karakteristikama hronološkog uzrasta ispitivanih grupa.

\section{Procjena motoričkog statusa za obe grupe ispitanika (Tabela br. 2)}

\begin{tabular}{|l|l|r|r|l|l|r|r|}
\hline & $\begin{array}{l}\text { grup } \\
\text { a }\end{array}$ & Mean & $\begin{array}{c}\text { Std. } \\
\text { Deviatio } \\
\mathrm{n}\end{array}$ & & $\begin{array}{l}\text { grup } \\
\mathrm{a}\end{array}$ & Mean & $\begin{array}{c}\text { Std. } \\
\text { Deviatio } \\
\mathrm{n}\end{array}$ \\
\hline mbtr & 1,00 & $\begin{array}{r}14,826 \\
1\end{array}$ & 6,90620 & mbtr & 2,00 & 26,2373 & 2,87881 \\
\hline mbtn & 1,00 & 9,2174 & 3,90753 & mbtn & 2,00 & 21,0339 & 3,34234 \\
\hline mbtnz & 1,00 & 9,7391 & 5,10986 & mbtnz & 2,00 & 17,7966 & 2,79642 \\
\hline mest20m & 1,00 & 5,3735 & 1,64895 & & 2,00 & 4,2468 &, 52075 \\
& & & $\begin{array}{l}\text { mest20 } \\
\text { m }\end{array}$ & & & \\
\hline messdm & 1,00 & $\begin{array}{r}75,944 \\
3\end{array}$ & $\begin{array}{r}44,9835 \\
5\end{array}$ & messdm & 2,00 & 151,762 & 24,17775 \\
\hline mrsptt & 1,00 & 8,7391 & 5,66663 & mrsptt & 2,00 & 22,0508 & 5,65815 \\
\hline
\end{tabular}




\begin{tabular}{|l|l|r|r|l|l|l|r|}
\hline mrsdć & 1,00 & $\begin{array}{r}17,434 \\
8\end{array}$ & 8,56964 & mrsdć & 2,00 & 33,4068 & 8,38331 \\
\hline mrsizz & 1,00 & 4,2743 & 8,53749 & mrsizz & 2,00 & 30,2542 & 20,36359 \\
\hline mkosdn & 1,00 & $\begin{array}{r}35,152 \\
2\end{array}$ & $\begin{array}{r}20,2530 \\
1\end{array}$ & mkosdn & 2,00 & 76,6271 & 20,32656 \\
\hline mkopzd & 1,00 & 9,9130 & 4,80448 & mkopzd & 2,00 & 12,7797 & 1,61958 \\
\hline $\begin{array}{l}\text { mkot10x } \\
5\end{array}$ & 1,00 & 26,532 & 4,52422 & & 2,00 & 21,5763 & 2,01891 \\
& & 5 & & $\begin{array}{l}\text { mkot10 } \\
\text { x5 }\end{array}$ & & & \\
\hline mfdp & 1,00 &,- 4000 & 7,25766 & mfdp & 2,00 & 3,3051 & 4,48082 \\
\hline mfip & 1,00 & $\begin{array}{r}73,863 \\
6\end{array}$ & $\begin{array}{r}15,7640 \\
\text { mfip }\end{array}$ & 2,00 & 52,5593 & 10,31114 \\
\hline mfpsr & 1,00 & $\begin{array}{r}48,565 \\
2\end{array}$ & $\begin{array}{r}22,9739 \\
5\end{array}$ & mfpsr & 2,00 & 99,6949 & 16,11944 \\
\hline
\end{tabular}

\section{Analiza razlika motoričkog statusa između dviju grupa ispitanika}

Tabela br. 3: Rezultati T-testa

\begin{tabular}{|l|c|c|c|r|r|r|}
\hline & & Sig. & \multicolumn{1}{c|}{$\mathbf{t}$} & Df & Sig. (2) & $\begin{array}{c}\text { Dean } \\
\text { Difference }\end{array}$ \\
\hline mbtr & 20,514 &, 000 & $\mathbf{- 1 0 , 6 1 5}$ & 80 & $\mathbf{, 0 0 0}$ & $-11,41120$ \\
\hline & & & $-\mathbf{7 , 6 6 9}$ & 25,038 & $\mathbf{, 0 0 0}$ & $-11,41120$ \\
\hline mbtn &, 429 &, 515 & $\mathbf{- 1 3 , 7 0 7}$ & 80 & $\mathbf{, 0 0 0}$ & $-11,81651$ \\
\hline & & & $\mathbf{- 1 2 , 7 9 3}$ & 35,251 & $\mathbf{, 0 0 0}$ & $-11,81651$ \\
\hline mbtnz & 10,516 &, 002 & $\mathbf{- 9 , 1 4 4}$ & 80 & $\mathbf{, 0 0 0}$ & $-8,05748$ \\
\hline & & & $-\mathbf{7 , 1 5 6}$ & 27,296 & $\mathbf{, 0 0 0}$ & $-8,05748$ \\
\hline mest20m & 21,242 &, 000 & $\mathbf{4 , 7 1 7}$ & 80 & $\mathbf{, 0 0 0}$ & 1,12670 \\
\hline & & & $\mathbf{3 , 2 1 5}$ & 23,730 & $\mathbf{, 0 0 4}$ & 1,12670 \\
\hline messdm & 24,112 &, 000 & $\mathbf{- 9 , 8 5 1}$ & 80 & $\mathbf{, 0 0 0}$ & $-75,81836$ \\
\hline & & & $\mathbf{- 7 , 6 6 3}$ & 27,104 & $\mathbf{, 0 0 0}$ & $-75,81836$ \\
\hline mrsptt &, 010 &, 921 & $\mathbf{- 9 , 5 6 7}$ & 80 & $\mathbf{, 0 0 0}$ & $-13,31172$ \\
\hline & & & $\mathbf{- 9 , 5 6 0}$ & 40,125 & $\mathbf{, 0 0 0}$ & $-13,31172$ \\
\hline mrsdć &, 003 &, 957 & $\mathbf{- 7 , 7 0 3}$ & 80 & $\mathbf{, 0 0 0}$ & $-15,97200$ \\
\hline & & & $\mathbf{- 7 , 6 2 8}$ & 39,397 & $\mathbf{, 0 0 0}$ & $-15,97200$ \\
\hline
\end{tabular}




\begin{tabular}{|l|r|r|r|r|r|r|}
\hline mrsizz & 54,459 &, 000 & $\mathbf{- 5 , 9 0 2}$ & 80 & $\mathbf{, 0 0 0}$ & $-25,97989$ \\
\hline & & & $\mathbf{- 8 , 1 3 6}$ & 79,490 & $\mathbf{, 0 0 0}$ & $-25,97989$ \\
\hline mkosdn &, 103 &, 749 & $\mathbf{- 8 , 3 0 9}$ & 80 & $\mathbf{, 0 0 0}$ & $-41,47494$ \\
\hline & & & $\mathbf{- 8 , 3 2 2}$ & 40,312 & $\mathbf{, 0 0 0}$ & $-41,47494$ \\
\hline mkopzd & 28,035 &, 000 & $\mathbf{- 4 , 0 6 0}$ & 80 & $\mathbf{, 0 0 0}$ & $-2,86662$ \\
\hline & & & $-\mathbf{2 , 8 0 0}$ & 23,974 & $\mathbf{, 0 1 0}$ & $-2,86662$ \\
\hline mkot10x5 & 21,597 &, 000 & $\mathbf{6 , 7 2 2}$ & 77 & $\mathbf{, 0 0 0}$ & 4,95623 \\
\hline & & & $\mathbf{4 , 7 4 2}$ & 21,619 & $\mathbf{, 0 0 0}$ & 4,95623 \\
\hline mfdp & 3,343 &, 071 & $\mathbf{- 2 , 7 0 0}$ & 77 & $\mathbf{, 0 0 9}$ & $-3,70508$ \\
\hline & & & $\mathbf{- 2 , 1 4 8}$ & 24,095 & $\mathbf{, 0 4 2}$ & $-3,70508$ \\
\hline mfip & 11,258 &, 001 & $\mathbf{7 , 1 0 4}$ & 79 & $\mathbf{, 0 0 0}$ & 21,30431 \\
\hline & & & $\mathbf{5 , 8 8 7}$ & 27,977 & $\mathbf{, 0 0 0}$ & 21,30431 \\
\hline mfpsr & 6,670 &, 012 & $\mathbf{- 1 1 , 3 8 9}$ & 80 & $\mathbf{, 0 0 0}$ & $-51,12970$ \\
\hline & & & $\mathbf{- 9 , 7 7 6}$ & 30,824 & $\mathbf{, 0 0 0}$ & $-51,12970$ \\
\hline
\end{tabular}

Metodom T-testa (Sig.2-tailed) prikazana je procjena statističke značajnosti, te možemo izvesti određene zaključke.

U pogledu motoričkih varijabli, a na osnovu signifikantne vrijednosti (.000), možemo zaključiti da postoji velika razlika izmeđ dviju grupa ispitanika. Bolji rezultati su na strani ispitanika koji nemaju tjelesnih i mentalnih nedostataka i koji su pohađali nastavu tjelesnog odgoja po redovnom planu i programu u svim varijablama motoričkog prostora. Razlike su evidentne u svim varijablama motoričkog prostora tako da sa sigurnošću možemo tvrditi da su učenici koji dolaze iz normalne populacije motorički superioniji u odnosu na učenike sa mentalnom retardacijom. Učenici9 sa retardacijom imali su mnogo lošije rezultate naročito u testovima koordinacije, gdje se retardacija odrazila i na to da su učenici sa retardacijom postizali nulte rezultate. To znači da nisu mogli ni izvesti testove koji su predstavnici koordinacije, što znači da su oni i preteški za njih. Koordinacija je itekako bitna osobina a povezana je i sa nervnom $\mathrm{i}$ unutarmišićnom koordinacijom te se iz tih razloga $\mathrm{i}$ odrazila na ukupne rezultate u motoričkih sposobnostima. 
Analiza razlika morfološkog statusa između dviju grupa ispitanika

Tabela br. 4: Rezultati T-testa

\begin{tabular}{|c|c|c|c|c|c|c|}
\hline & $\mathbf{F}$ & Sig. & $\mathbf{t}$ & df & $\begin{array}{c}\text { Sig. } \\
\text { (2-tailed) }\end{array}$ & $\begin{array}{c}\text { Mean } \\
\text { Difference } \\
\end{array}$ \\
\hline \multirow[t]{2}{*}{ avis } & 9,364 & $\begin{array}{r}00 \\
3\end{array}$ & ,278 & 80 & ,782 & ,63832 \\
\hline & & & ,222 & $\begin{array}{r}28,07 \\
2\end{array}$ & ,826 & ,63832 \\
\hline \multirow[t]{2}{*}{ adur } & $\begin{array}{r}32,22 \\
7\end{array}$ & $\begin{array}{r}, 00 \\
0\end{array}$ & 1,457 & 80 & ,149 & 2,01142 \\
\hline & & & ,996 & $\begin{array}{r}23,79 \\
4\end{array}$ & ,329 & 2,01142 \\
\hline \multirow[t]{2}{*}{ adus } & $\begin{array}{r}13,31 \\
4\end{array}$ & $\begin{array}{r}, 00 \\
0\end{array}$ & 3,087 & 80 & ,003 & 1,27155 \\
\hline & & & 2,426 & $\begin{array}{r}27,43 \\
2\end{array}$ & ,022 & 1,27155 \\
\hline \multirow[t]{2}{*}{ abiar } & ,204 & $\begin{array}{r}, 65 \\
3\end{array}$ & 5,959 & 80 & ,000 & 4,72837 \\
\hline & & & 5,638 & $\begin{array}{r}36,12 \\
3\end{array}$ &, 000 & 4,72837 \\
\hline \multirow[t]{2}{*}{ abikr } & $\begin{array}{r}24,88 \\
0\end{array}$ & $\begin{array}{r}, 00 \\
0\end{array}$ & ,473 & 80 & ,638 & ,24112 \\
\hline & & & ,340 & $\begin{array}{r}24,96 \\
1\end{array}$ & ,736 & ,24112 \\
\hline \multirow[t]{2}{*}{ adirz } & 2,459 & $\begin{array}{r}12 \\
1\end{array}$ &, 573 & 80 &, 568 & ,05906 \\
\hline & & & ,499 & $\begin{array}{r}31,47 \\
9\end{array}$ & ,621 & ,05906 \\
\hline \multirow[t]{2}{*}{ adiko } & 8,938 & $\begin{array}{r}, 00 \\
4\end{array}$ & 3,624 & 80 & ,001 &, 83080 \\
\hline & & & 2,875 & $\begin{array}{r}27,74 \\
2 \\
\end{array}$ & ,008 & ,83080 \\
\hline aknı & $\begin{array}{r}51,59 \\
7\end{array}$ & $\begin{array}{r}, 00 \\
0\end{array}$ & 7,554 & 80 &, 000 & 9,26466 \\
\hline
\end{tabular}




\begin{tabular}{|c|c|c|c|c|c|c|}
\hline & & & 5,207 & $\begin{array}{r}23,96 \\
5\end{array}$ &, 000 & 9,26466 \\
\hline \multirow[t]{2}{*}{ aknle } & $\begin{array}{r}97,85 \\
6\end{array}$ & $\begin{array}{r}, 00 \\
0\end{array}$ & $\begin{array}{r}10,33 \\
5\end{array}$ & 80 &, 000 & $\begin{array}{r}13,9251 \\
6\end{array}$ \\
\hline & & & 6,934 & $\begin{array}{r}23,41 \\
3\end{array}$ &, 000 & $\begin{array}{r}13,9251 \\
6\end{array}$ \\
\hline \multirow[t]{2}{*}{ akntr } & $\begin{array}{r}54,71 \\
7\end{array}$ & $\begin{array}{r}, 00 \\
0\end{array}$ & 6,582 & 80 &, 000 & 8,91716 \\
\hline & & & 4,550 & $\begin{array}{r}24,02 \\
3\end{array}$ &, 000 & 8,91716 \\
\hline \multirow[t]{2}{*}{ aogk } & $\begin{array}{r}72,45 \\
3 \\
\end{array}$ & $\begin{array}{r}, 00 \\
0\end{array}$ & 8,160 & 80 &, 000 & $\begin{array}{r}14,9599 \\
9\end{array}$ \\
\hline & & & 5,232 & $\begin{array}{r}22,58 \\
9\end{array}$ &, 000 & 14,95999 \\
\hline \multirow[t]{2}{*}{$\begin{array}{l}\text { aopot } \\
\mathrm{k}\end{array}$} & $\begin{array}{r}27,51 \\
8 \\
\end{array}$ & $\begin{array}{r}, 00 \\
0 \\
\end{array}$ & 4,333 & 80 &, 000 & 3,60081 \\
\hline & & & 3,171 & $\begin{array}{r}25,35 \\
8\end{array}$ & ,004 & 3,60081 \\
\hline \multirow[t]{2}{*}{$\begin{array}{l}\text { aona } \\
\text { dl }\end{array}$} & $\begin{array}{r}58,72 \\
4 \\
\end{array}$ & $\begin{array}{r}, 00 \\
0\end{array}$ & 5,838 & 80 &, 000 & 3,96566 \\
\hline & & & 3,881 & $\begin{array}{r}23,23 \\
8\end{array}$ & ,001 & 3,96566 \\
\hline \multirow[t]{2}{*}{ atež } & $\begin{array}{r}39,56 \\
4 \\
\end{array}$ & $\begin{array}{r}, 00 \\
0\end{array}$ & 5,627 & 80 &, 000 & 3,26825 \\
\hline & & & 3,932 & $\begin{array}{r}24,26 \\
0\end{array}$ & ,001 & 4,67685 \\
\hline
\end{tabular}

Također analizom dobijenih rezultata morfoloških karakteristika uz pomoć T-testa, a na osnovu signifikantne vrijednosti (sig. .000), možemo konstatovati da u varijablama ABIKR, ADIRZ, ADUR i AVIS ne postoji statistička značajnost, što je karakteristično za obadvije ispitivane populacije, a što u suštini vjerovatno možemo povezati sa morfološkim karakteristikama hronološkog uzrasta ispitivane populacije. To nam govori vjerovatno o tome da su ispitanici obiju grupa sličnog morfološkog razvoja kada su u pitanju longitudinalne $i$ transverzalna dimenzionalnost skeleta $i \mathrm{u}$ tim latentnim dimenzijama nije došlo do statističke značajnosti. Međutim, u analizi mase i volumnoznosti tijela kao i potkožnog masnog tkiva 
postoji izuzetno velika razlika između ovih dviju grupa ispitanika. Veći rezultati su kod ispitanika grupe retardiranih učenika.

$\mathrm{Na}$ osnovu ovih rezultata morfoloških karakteristika sasvim je razumljivo i opravdano jer su bolji rezultati ispitanika koji dolaze iz populacije učenika koji nastavu pohađaju po standardnom normalnom programu i koji ne spadaju u grupu retardiranih. Razlika u težini između dviju grupa ispitanika je i do $18 \mathrm{~kg}$ što se direktno odrazilo na rezultate u motoričkim sposobnsotima.

\section{ZAKLJUČAK}

Tjelesni odgoj temelji se na mogućnosti poticanja fizičkog rasta i razvoja djece i omladine, razvoju psihomotoričkog sistema i opće funkcionalne sposobnosti organizma. Ovaj zadatak se ostvaruje osmišljenim sistemom vježbi, igara, stvaranju navika na zdrav i higijenski život, ispravnim držanjem tijela. Svako dijete stječe spoznaju o općem fizičkom stanju i stvara naviku bavljenja tjelesnim aktivnostima. U ovom radu smo utvrdili velike razlike u nivou motoričkih sposobnosti i nekih morfoloških karakteristika. Velika razlika je konstatirana u morfološkim karakteristika kod učenika koji su pokazivali jedan od stepena retardacije u odnosu na učenike iz normalne populacije bez retardacije, naročito kad je u pitanju masa i volumen tijela i transverzalna dimenzionalnost skeleta. Kad je u pitanju masa tijela, učenici sa retardacijom su bili u prosjeku teži i do $18 \mathrm{~kg}$. To se, naravno, odrazilo i na druge morfološke karakteristike a zbog velike povezanosti svih antropoloških obilježja, svakako se statistički značajno odrazilo i na razlike u motoričkim sposobnostima. Neke testove kao što su npr. testovi koordincije učenici sa retardacijom nisu mogli nikako izvoditi, posebno test skok u dalj natraške, koji je tipičan test predstavnik reorganizcije stereotipa gibanja. Koordincija je jedna od bitnijih motoričkih sposobnosti koja zavisi i od kognitivnog faktora koji se u suštini naziva G-faktor ili inteligencija, što se u ovom radu i dokazalo. Dalje, velike rezlike su u testovima brzine koja također ima veliku korelaciju sa testovima koordinacije tako da se to odrazilo i na ove rezultate. Na osnovu svega do sada izloženog možemo sa sigaurnošču tvrditi da su učenici sa mentalnom retardacijom pokazali mnogo slabije rezultate u svim motoričkim i morfološkim karakteristikama. Naravno, znajući koliko 
je pokret bitan u normalnom stvaranju ličnosti moglo se zaključiti i da učenici sa većim stepenom retardacije imaju lošije motoričke sposobnosti. Tjelesno vježbanje direktno utiče na centralni nervni sistem, u smislu da se povećava nervna osjetljivost organizma što je kretanje veće, odnosno što je veće vježbanje, bolja je i koordinacija pokreta.

Međutim, jedno od pitanje ovog rada jeste: šta je sa roditeljima koji imaju djecu s posebnim potrebama, kolika je njihova tuga i bol, koliko je to njihovo odricanje da bi pomogli najvoljenijim, kojima se u suštini i ne može pomoći da se osim nekad u većoj a ponekad u manjoj mjeri - normalno uključe u životne tokove; kako ublažiti tjekobe sa kojima su osuđeni da žive? Neizostavno se nameću pitanja šta sa njima, na koji način pružiti pomoć, u bilo kom smislu, kako bismo ih učinili iole sretnim i sposobnim za izvođenje osnovnih životnih potreba. Sport je jedan od najvažnijih oblika ispoljavanja njihovih želja i težnji.

Značaj tjelesnog vježbanja ogleda se u širokom spektru sposobnosti na koje vježbanje utiče, ali i u razvoju mnogih osobina. Tjelesna vježba, ovisno o tome na koji dio tijela je ograničena, ima svoje opće i pojedinačne zadatke čiji kvalitet uticaja isključivo zavisi od pravilnog izvođenja vježbe. Svakodnevno vježbanje dovodi do stvaranja pozitivnih navika kod djece, a to je potreba za kretanjem i aktivnošću.

Tjelesno vježbanje je značajno i po tome što vrši uticaj na biološke karakteristike i fiziološke sposobnosti organizma,

Tjelesno vježbanje u biološkom smislu utiče na razvoj pojedinih dijelova organizma i poboljšanje funkcionalnih sposobnosti u organizmu.

Fiziološki uticaj tjelesnog vježbanja ogleda se u poboljšanju funkcionalnih sposobnosti organizma djece i odraslih, pod uticajem fizičkog opterećenja tjelesnog vježbanja, a ogleda se kroz: rast i razvoj koštanog sistema, povećanje mišićne zapremine, jačanje zglobnih veza, poboljšanje cirkulacije krvi kroz organizam, jačanje srčanog mišića, bolju snabdjevenost svih organa hranjivim materijama putem krvi, poboljšanje primitka kisika zbog povećanja zapremine i kapaciteta pluća, kao posljedice tjelesnog vježbanja, lakše varenje hrane i pojačana potreba za njenim unošenjem u organizam, poboljšana kontrakcija trbušnih mišića i peristaltika crijeva. 
Zdrave, okretne, spretne i vješte osobe mogu lakše "nositi" sve nedaće i teškoće života te mogu lakše obavljati svoje radne i društvene zadaće.

\section{LITERATURA}

1. Američko psihijatarska udruga (1996) Dijagnostički $i$ statistički priručnik za društvene poremećaje (DSM IV. Naklada Slap, Jastebarsko.

2. Berberović, Lj., Hadžiselimović, R. (1982) Rast i razvoj ljudskog organizma. Svjetlost, Sarajevo.

3. Berberović, Lj, Hadžiselimović, R., Dizdarević, M. (1990) Glavni periodi rasta i razvoja jedinke. Svjetlost, Sarajevo, str. 42-46.

4. Dašen, A. (1994) Psihijatarski poremećaji djece i mladeži sa mentalnom retardacijom. Defektologija, 30/2, 7, Zagreb, 160-185.

5. Došen, A., Kocijan, D.,. Kozarić, D. (2001) Mentalna retardacija. Zagreb.

6. Horga, S. (1976) O nekim relacijama između aneksioznosti $i$ koordinacije. Disertacija, Fakultet za fizičku kulturu, Zagreb.

7. Hošek, A. (1976) Struktura koordinacije. Kineziologija, Zagreb.

8. Memić, S. (2006) Transformacioni procesi baznih motoričkih sposobnosti pod uticajem eksperimentalnog programa kod učenika sa posebnim potrebama. Magistarski rad, Tuzla.

9. Skender, N. (2001) Relacije tjelesnih deformiteta i motoričkih sposobnosti učenika uzrasta 15-16 godina. Magistarski rad, Sarajevo.

10. Skender, N. Kendić, S.(2002) Tjelesni i zdravstveni odgoj $u$ funkciji korekcije deformiteta lokomotornog sistema. Pedagoški zavod, Bihać.

11. Thomson E., Adams J. A. (1972) A.Closeed-Loop Theory of Motor Learning. Behavior, 3, -111.

12. Šoše, H. Rađo, I., Mekić, M. (1998) Vodić za pisanje naučnih $i$ stručnih radova u kineziologoji. Fakultet za fizičku kulturu, Sarajevo. 


\section{NIJAZ SKENDER, SENIOR LECTURER \\ SULEJMAN KENDIĆ, P.H.D.}

\section{ANALYSIS OF SOME ANTROPOLOGICAL FEATURES BETWEEN STUDENTS WITH SPECIAL NEEDS AND NORMAL STUDENTS}

\section{SUMMARY}

The children with special needs should be care of every society and more attention should be paid to them. Such children are separated in many communities and go to special schools. Fortunately these schools are decreasing in number, because there is intention to include them into regular schools. However, if the degree of retardation is too high and disables them to follow the standard syllabus, they go to special schools.

In previous researches great correlations have been spotted between certain anthropological features and levels of retardation. In this work we have concluded that students with the high level of retardation differentiate largely in morphological characteristics and movement abilities. These differences were huge, students with mental retardation were $18 \mathrm{~kg}$ heavier than normal students of the same age. That of course had impact on their movement abilities, especially on coordination which is very important for a complete motorical movement. Students with mental retardation have shown a much lower level of movement abilities in general than the students who came from the normal population because the movement abilities are in important correlation with all psychological manifestations in people.

By working on developing of movement abilities we ca definitely affect the improvement of their psycho-physic functions. 


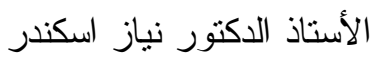

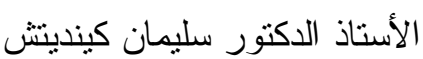

\section{تحليل فروق بعض العلامات الأثثروبولوجية}

بين التلاميذ ذوي الاحتياجات الخاصة و التلاميذ العاديين

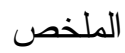

التلاميذ ذوو الاحتياجات الخاصة يجب أن بحظو ا بالاهتمام من جميع المجتمعات



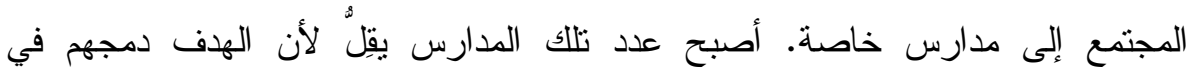
المدارس العادية، ولكن هناك حالات نكون درجة الإعاقة عالية بحيث تعبق متابعة

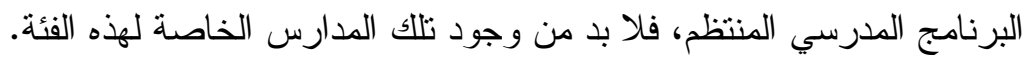


ومستوى الإعاقة العقلية.

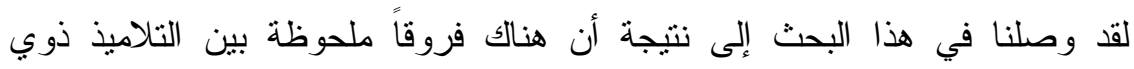

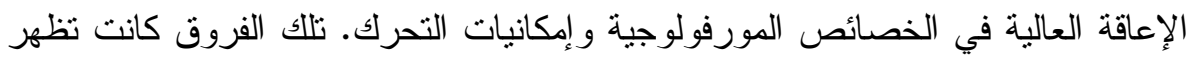

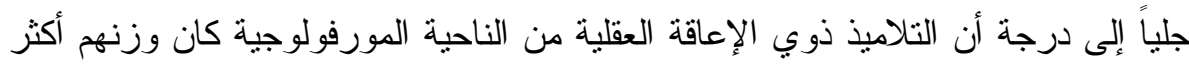

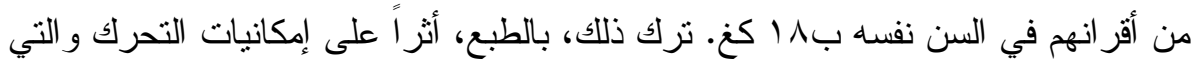

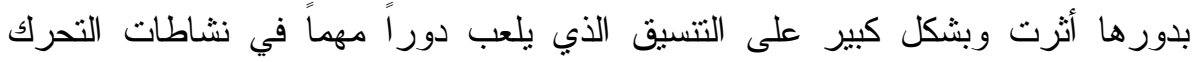
بأكمله.

التلاميذ ذوو الإعاقة العقلية أظهروا مستويً متنّياً من إمكانيات التحرك إذا قارناهم بالتلاميذ العاديين، لأن إمكانيات التحرك في علاقة متبادلة ببقية المظاهر النفسية. إن تتمية أمكانيات التحرك تؤثر بشكل مؤكد على تحسين الوظائف النفسية. 